Article

\title{
Hydrochlorination of Acetylene Catalyzed by an Activated Carbon-Supported Ammonium Hexachlororuthenate Complex
}

\author{
Junjie Gu, Yumiao Gao, Jinli Zhang, Wei Li, Yanzhao Dong and You Han * \\ School of Chemical Engineering \& Technology, Tianjin University, Tianjin 300350, China; \\ Junjie_gu@carleton.ca (J.G.); gaoym2016@163.com (Y.G.); zhangjinli@tju.edu.cn (J.Z.); \\ liwei@tju.edu.cn (W.L.); yzdong@tju.edu.cn (Y.D.) \\ * Correspondence: yhan@tju.edu.cn; Tel.: +86-22-278-90643 \\ Academic Editors: Albert Demonceau, Ileana Dragutan and Valerian Dragutan \\ Received: 2 November 2016; Accepted: 28 December 2016; Published: 10 January 2017
}

\begin{abstract}
Ammonium hexachlororuthenate $\left(\left(\mathrm{NH}_{4}\right)_{2} \mathrm{RuCl}_{6}\right)$ complex was used as a catalyst precursor and coconut activated carbon (AC) was used as the support in the preparation process of the Ru-based catalyst. $\left(\mathrm{NH}_{4}\right)_{2} \mathrm{RuCl}_{6} / \mathrm{AC}$ catalyst was prepared via an incipient wetness impregnation method and assessed in an acetylene hydrochlorination reaction. Meanwhile, the $\left(\mathrm{NH}_{4}\right)_{2} \mathrm{RuCl}_{6} / \mathrm{AC}$ catalyst was analyzed with low-temperature $\mathrm{N}_{2}$ adsorption/desorption, thermogravimetry (TG), transmission electron microscopy (TEM), temperature programmed reduction (TPR), X-ray photoelectron spectra (XPS), and temperature programmed desorption (TPD) techniques. Catalytic performance test results show that the $\left(\mathrm{NH}_{4}\right)_{2} \mathrm{RuCl}_{6} / \mathrm{AC}$ catalyst exhibits a superior catalytic activity with the highest acetylene conversion of $90.5 \%$ under the conditions of $170{ }^{\circ} \mathrm{C}$ and an acetylene gas hourly space velocity of $180 \mathrm{~h}^{-1}$. The characterization results illustrate that the presence of the $\mathrm{NH}_{4}{ }^{+}$cation can inhibit coke deposition as well as the agglomeration of ruthenium particles, and it can also enhance the adsorption ability for reactant $\mathrm{HCl}$, hence improving the catalytic activity and stability.
\end{abstract}

Keywords: acetylene hydrochlorination; Ru complex catalysts; heterogeneous catalysis

\section{Introduction}

Polyvinyl chloride (PVC), one of the most important plastics, is synthesized via the polymerization of the vinyl chloride monomer (VCM). In China, VCM is commonly manufactured through the acetylene hydrochlorination reaction catalyzed by the activated carbon-supported mercuric chloride catalyst $\left(\mathrm{HgCl}_{2} / \mathrm{AC}\right)$, which is due to the national characteristic of abundant coal sources and a relative lack of oil [1,2]. However, $\mathrm{HgCl}_{2}$ is a kind of poisonous and volatile compound, damaging the environment and human health. In 2013, the Minamata convention on mercury clearly curbed the application of products containing mercury on a global scale in 2020 [3]. Consequently, it is encouraged to explore a green non-mercury catalyst to substitute the $\mathrm{HgCl}_{2}$ catalyst for acetylene hydrochlorination reaction.

In 1968, Smith et al. carried out a series of silica-supported metal chloride catalysts for acetylene hydrochlorination, and concluded that catalytic activity could be correlated with the electron affinity of the metallic cation [4]. Next, in 1975, Shinoda studied over 20 types of metal chlorides for acetylene hydrochlorination reaction [5]. By analyzing Shionda's experimental data, Hutchings concluded that the activity of metal catalysts in acetylene hydrochlorination was correlated with the standard electrode potential of corresponding metal cations and confirmed that the $\mathrm{AuCl}_{3}$ catalyst exhibited the optimal catalytic activity [6]. Subsequently, abundant studies have been implemented to develop the Au-based catalysts [7-21]. However, the Au-based catalyst is very precious. Hence, exploring a low cost catalyst 
has attracted much attention. In 2012, Zhu et al. employed density functional theory (DFT) to calculate the activation barrier of the catalysts $\mathrm{MCl}_{x}(\mathrm{M}=\mathrm{Hg}$, Au, $\mathrm{Ru} ; x=2,3)$ for acetylene hydrochlorination, and found that the activation barriers were 16.3, 11.9, and $9.1 \mathrm{kcal} \cdot \mathrm{mol}^{-1}$ for $\mathrm{HgCl}_{2}, \mathrm{AuCl}_{3}$, and $\mathrm{RuCl}_{3}$, respectively. The results indicated that the comparatively inexpensive Ru-based catalyst might be a good candidate catalyst for the acetylene hydrochlorination reaction [22]. Zhang et al. reported that $1 \% \mathrm{Ru} / \mathrm{SAC}$ catalyst showed an acetylene conversion of $91 \%$ after $48 \mathrm{~h}$ reaction under the condition of $170{ }^{\circ} \mathrm{C}$ [23]. In order to further enhance the catalytic activity and stability of Ru-based catalysts, researchers have done many studies, including the addition of other metallic additives (Ru-K/SAC [24], $\mathrm{Ru}-\mathrm{Cu} / \mathrm{MWCNTs}$ [25], Ru-Co-Cu/SAC [26]) and the modification of carbon support (Ru-in-CNT [27], $\mathrm{Ru} / \mathrm{SAC}-\mathrm{N}$ [28], $\mathrm{Ru} / \mathrm{AC}-\mathrm{NHN}$ [29]). For instance, $\mathrm{Xu}$ et al. reported that Ru-Cu catalyst with carbon nanotubes as the support (Cu400Ru/MWCNTs) exhibited an acetylene conversion of $51.6 \%$ under the reaction conditions of $180{ }^{\circ} \mathrm{C}, V(\mathrm{HCl}) / V\left(\mathrm{C}_{2} \mathrm{H}_{2}\right)=1.2$ and an acetylene gas hourly space velocity (GHSV) of $180 \mathrm{~h}^{-1}$ [25]. Although these Ru-based catalysts showed a certain increase in the catalytic activities, an effort should be made to further develop a novel and efficient catalyst with high activity and long-term stability fit for industrial application.

Recently, ligand-modified Au-based catalysts and gold complex catalysts (such as $\mathrm{Na}_{3} \mathrm{Au}\left(\mathrm{S}_{2} \mathrm{O}_{3}\right)_{2} / \mathrm{AC},\left[\mathrm{AuCl}_{2}\right.$ (phen)]Cl/AC and $\mathrm{AuPPh}_{3} \mathrm{Cl} / \mathrm{AC}$ ) have been applied in the acetylene hydrochlorination reaction, and exhibited excellent catalytic activity and stability [30-33]. Meanwhile, ligand-modified Ru-based catalysts and ruthenium complex catalysts have also been reported in the hydrogenation or hydrochlorination reaction. Vilé et al. studied the ligand-modified $\mathrm{Ru}-\mathrm{HHDMA} / \mathrm{TiSi}_{2} \mathrm{O}_{6}$ (HHDMA = hexadecyl(2-hydroxyethyl)dimethylammonium dihydrogen phosphate) catalyst in the hydrogenation of levulinic acid to gamma-valerolactone, and found that the synthetic Ru-HHDMA $/ \mathrm{TiSi}_{2} \mathrm{O}_{6}$ catalyst $(0.24 \mathrm{wt} \% \mathrm{Ru})$ exhibited a four-fold higher reaction rate than that of the commercial $5 \mathrm{wt} \% \mathrm{Ru} / \mathrm{C}$ catalyst [34]. Particularly, Dérien et al. reported that ruthenium complex $[\mathrm{Cp} * \mathrm{RuCl}(\mathrm{cod})] / \mathrm{PPh}_{3}\left(\mathrm{Cp}^{*}=\mathrm{C}_{5} \mathrm{Me}_{5}, \mathrm{cod}=1,5\right.$-cyclooctadiene $)$ catalyst possessed excellent yields for hydrochlorination of terminal alkynes under the mild reaction, and mechanistic studies suggested that a chlorohydrido $\mathrm{Ru}(\mathrm{IV})$ species was a critical intermediate in this reaction [35]. This is consistent with our previous findings that the $\mathrm{Ru}(\mathrm{IV})$ species is considered as the major active ingredient in acetylene hydrochlorination reaction [36].

However, to the best of our knowledge, ruthenium complex catalysts have not been reported for the acetylene hydrochlorination reaction. Therefore, ruthenium(IV) complexes with abundant $\mathrm{Ru}(\mathrm{IV})$ species could possess high activity and attracted our interest. Among various ruthenium(IV) complexes, complex ammonium hexachlororuthenate, $\left(\mathrm{NH}_{4}\right)_{2} \mathrm{RuCl}_{6}$, is commercially available and easily prepared. In this work, we prepared the $\left(\mathrm{NH}_{4}\right)_{2} \mathrm{RuCl}_{6} / \mathrm{AC}$ catalyst via an incipient wetness impregnation method and assessed their catalytic activity in the acetylene hydrochlorination reaction. The result of catalytic activity indicated that the $\left(\mathrm{NH}_{4}\right)_{2} \mathrm{RuCl}_{6} / \mathrm{AC}$ catalyst exhibited excellent catalytic activity and stability. Low-temperature $\mathrm{N}_{2}$ adsorption/desorption, thermogravimetry (TG), transmission electron microscopy (TEM), temperature programmed reduction (TPR), X-ray photoelectron spectra (XPS), and temperature programmed desorption (TPD) characterization techniques were applied to analyze the Ru-based catalysts.

\section{Results and Discussion}

\subsection{Catalytic Performance of Ru-Based Catalysts}

Figure 1 displays the catalytic performances of these Ru-based catalysts for the acetylene hydrochlorination reaction. It can be seen that the $\mathrm{NH}_{4} \mathrm{Cl} / \mathrm{AC}$ catalyst exhibits a catalytic activity which is as low as the support AC. The result indicates that the $\mathrm{NH}_{4} \mathrm{Cl}$ species has no catalytic activity for this reaction. The $\mathrm{RuCl}_{3} / \mathrm{AC}$ catalyst shows an initial acetylene conversion of $78.8 \%$, and decreases to $68.2 \%$ after $48 \mathrm{~h}$ reaction (Figure 1a). While for the complex $\left(\mathrm{NH}_{4}\right)_{2} \mathrm{RuCl}_{6} / \mathrm{AC}$ catalyst, the acetylene conversion is $90.5 \%$ initially, and then decreases to $87.3 \%$ after $48 \mathrm{~h}$ reaction, 
which is higher than that of monometallic $\mathrm{RuCl}_{3} / \mathrm{AC}$ catalyst. Moreover, the selectivity to VCM of $\left(\mathrm{NH}_{4}\right)_{2} \mathrm{RuCl}_{6} / \mathrm{AC}$ is slightly higher than that of the $\mathrm{RuCl}_{3} / \mathrm{AC}$. Thus, the $\left(\mathrm{NH}_{4}\right)_{2} \mathrm{RuCl}_{6} / \mathrm{AC}$ catalyst shows higher catalytic activity and stability compared to the monometallic $\mathrm{RuCl}_{3} / \mathrm{AC}$ catalyst for acetylene hydrochlorination reaction.
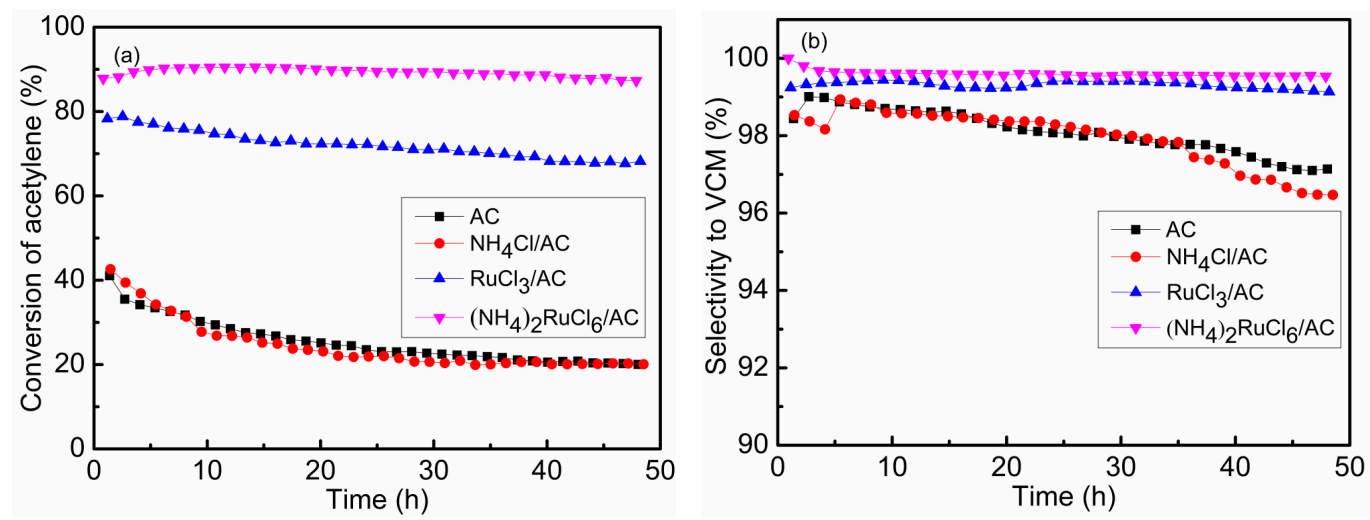

Figure 1. Acetylene conversion (a) and selectivity to Vinyl Chloride Monomer (VCM) (b) over activated carbon (AC), $\mathrm{NH}_{4} \mathrm{Cl} / \mathrm{AC}, \mathrm{RuCl}_{3} / \mathrm{AC}$, and $\left(\mathrm{NH}_{4}\right)_{2} \mathrm{RuCl}_{6} / \mathrm{AC}$ catalysts. Reaction conditions: $\mathrm{T}=170{ }^{\circ} \mathrm{C}$, $\operatorname{GHSV}\left(\mathrm{C}_{2} \mathrm{H}_{2}\right)=180 \mathrm{~h}^{-1}, V(\mathrm{HCl}) / V\left(\mathrm{C}_{2} \mathrm{H}_{2}\right)=1.1$, the Ru loading content $=1 \mathrm{wt} \%$.

\subsection{Catalyst Characterization}

\subsubsection{Catalyst Texture Properties}

Low-temperature $\mathrm{N}_{2}$ adsorption/desorption experiments are used to measure the specific surface area and pore volume, and the results are listed in Table 1. The specific surface areas and the pore volume of the fresh $\mathrm{RuCl}_{3} / \mathrm{AC}$ and complex $\left(\mathrm{NH}_{4}\right)_{2} \mathrm{RuCl}_{6} / \mathrm{AC}$ catalysts are lower than that of the support AC. This result might be attributed to the decrease of the support ratio in these catalysts. The reason for the decrease is due to the addition of the active component, and the phenomenon is known as the dilution effect [13]. For the fresh complex $\left(\mathrm{NH}_{4}\right)_{2} \mathrm{RuCl}_{6} / \mathrm{AC}$ catalyst, the specific surface area is $968 \mathrm{~m}^{2} \cdot \mathrm{g}^{-1}$, which is lower than that of the fresh $\mathrm{RuCl}_{3} / \mathrm{AC}$ catalyst $\left(1055 \mathrm{~m}^{2} \cdot \mathrm{g}^{-1}\right)$. This can be caused by the larger molecular structure of the complex $\left(\mathrm{NH}_{4}\right)_{2} \mathrm{RuCl}_{6}$ compared to the $\mathrm{RuCl}_{3}$. The larger molecular structure can block some support pores and result in a decline of the specific surface area and pore volume.

Table 1. Texture parameter of catalysts with Ru loading of $1.0 \mathrm{wt} \%{ }^{1}$.

\begin{tabular}{ccccccc}
\hline \multirow{2}{*}{ Samples } & \multicolumn{2}{c}{$\boldsymbol{S}_{\text {BET }}\left(\mathbf{m}^{\mathbf{2}} \cdot \mathbf{g}^{-\mathbf{1}}\right)$} & \multicolumn{2}{c}{$\boldsymbol{V}\left(\mathbf{c m}^{\mathbf{3}} \cdot \mathbf{g}^{-\mathbf{1}}\right)$} & \multicolumn{2}{c}{$\boldsymbol{D}(\mathbf{n m})$} \\
\cline { 2 - 6 } & Fresh & Used & Fresh & Used & Fresh & Used \\
\hline $\mathrm{AC}$ & 1168 & - & 0.60 & - & 2.08 & - \\
$\mathrm{RuCl}_{3} / \mathrm{AC}$ & 1055 & 640 & 0.55 & 0.34 & 2.32 & 2.24 \\
$\left(\mathrm{NH}_{4}\right)_{2} \mathrm{RuCl}_{6} / \mathrm{AC}$ & 968 & 708 & 0.51 & 0.36 & 2.30 & 2.20 \\
\hline & & &
\end{tabular}

After $48 \mathrm{~h}$ reaction, the specific surface areas and pore volume of catalysts is lower than those of the corresponding fresh catalysts. As shown in Table 1, the used $\mathrm{RuCl}_{3} / \mathrm{AC}$ catalyst exhibits a decline in the specific surface area and pore volume of $39.3 \%$ and $38.2 \%$, respectively. However, for the used $\left(\mathrm{NH}_{4}\right)_{2} \mathrm{RuCl}_{6} / \mathrm{AC}$ catalyst, the decline in the specific surface area and pore volume are $26.9 \%$ and $29.4 \%$, respectively. The result indicates that the carbon deposition on the surface of the catalyst occurs during the reaction owing to the polymerization of $\mathrm{C}_{2} \mathrm{H}_{2}$ and VCM. This is the reason why the catalytic activities of the $\mathrm{RuCl}_{3} / \mathrm{AC}$ and $\left(\mathrm{NH}_{4}\right)_{2} \mathrm{RuCl}_{6} / \mathrm{AC}$ catalysts decrease during the reaction. 
Additionally, more carbon deposition occurs on the $\mathrm{RuCl}_{3} / \mathrm{AC}$ catalyst in comparison with the complex $\left(\mathrm{NH}_{4}\right)_{2} \mathrm{RuCl}_{6} / \mathrm{AC}$ catalyst, indicating that the presence of $\mathrm{NH}_{4}{ }^{+}$in the complex $\left(\mathrm{NH}_{4}\right)_{2} \mathrm{RuCl}_{6}$ might inhibit the formation of coking deposition on the catalyst surface.

\subsubsection{Coke Deposition on the Used Catalysts}

TG analysis is used to show the amount of coke deposited on the used catalysts to explain the reason for the deactivation of catalysts. Figure 2 shows the TG analysis profiles of the both fresh and used $\mathrm{RuCl}_{3} / \mathrm{AC}$ and $\left(\mathrm{NH}_{4}\right)_{2} \mathrm{RuCl}_{6} / \mathrm{AC}$ catalysts. For all Ru-based catalysts, a slight mass loss is observed when the temperature is lower than $150{ }^{\circ} \mathrm{C}$, which is attributed to physically adsorbed water. With the temperature rising continuously from 150 to $360^{\circ} \mathrm{C}$, an obvious mass loss is observed for the used catalysts. When the temperature exceeds $360^{\circ} \mathrm{C}$, there is a rapid mass loss for all Ru-based catalysts owing to the burning of activated carbon. The amount of coke deposition is determined together by the mass loss of the fresh and the used catalysts in the temperature range of $150-360{ }^{\circ} \mathrm{C}$ and calculated using our previous method [33]. For the fresh and used $\mathrm{RuCl}_{3} / \mathrm{AC}$ catalysts, in the range of $150-360{ }^{\circ} \mathrm{C}$, the mass losses are $2.7 \%$ and $16.4 \%$, respectively, (Table S1). Assuming that the coke deposition amount on the used $\mathrm{RuCl}_{3} / \mathrm{AC}$ catalyst equals $X$, the following equations should be met, $100 / 2.7=(100-X) / Y$, and $Y+X=16.4$. Therefore, the amount of coke deposition is $14.1 \%$ for the used $\mathrm{RuCl}_{3} / \mathrm{AC}$ catalyst (Table 2 ).
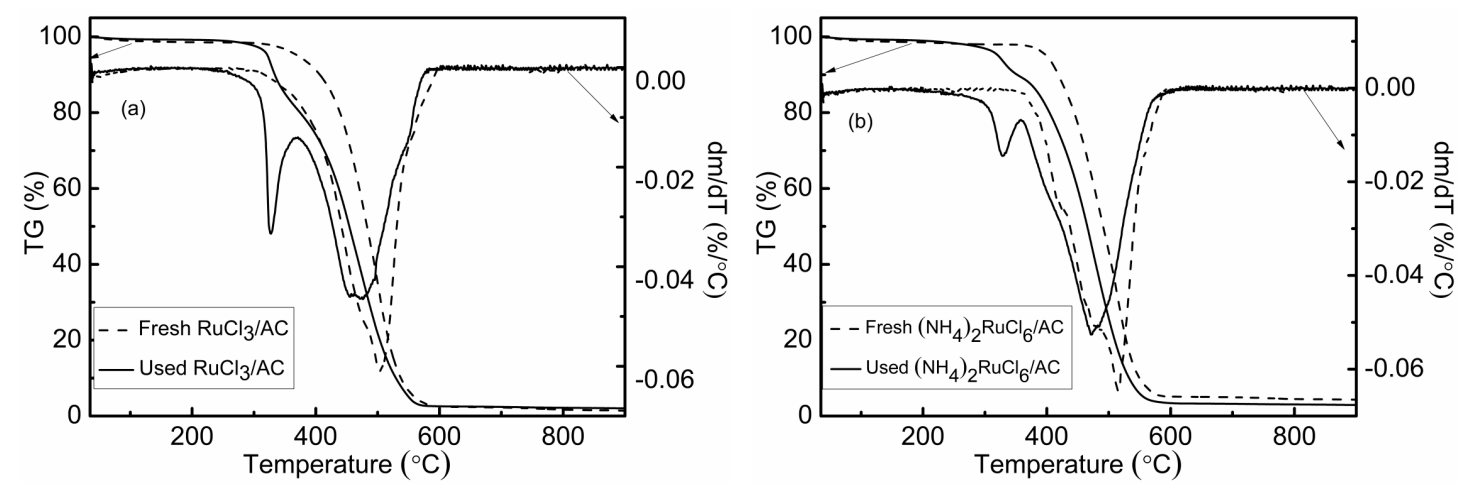

Figure 2. Thermogravimetric (TG) and derivative thermogravimetric (DTG) curves of the fresh and used 1.0 wt \% Ru-based catalysts (a) $\mathrm{RuCl}_{3} / \mathrm{AC}$; (b) $\left(\mathrm{NH}_{4}\right)_{2} \mathrm{RuCl}_{6} / \mathrm{AC}$.

Table 2. The amount of coke deposition on the used $1.0 \mathrm{wt} \% \mathrm{Ru}$-based catalysts.

\begin{tabular}{cc}
\hline Catalyst & Amount of Coke Deposition (\%) \\
\hline $\mathrm{RuCl}_{3} / \mathrm{AC}$ & 14.1 \\
$\left(\mathrm{NH}_{4}\right)_{2} \mathrm{RuCl}_{6} / \mathrm{AC}$ & 9.2 \\
\hline
\end{tabular}

Similarly, the amount of coke deposition on the complex $\left(\mathrm{NH}_{4}\right)_{2} \mathrm{RuCl}_{6} / \mathrm{AC}$ catalyst is calculated based on the above method. The mass losses are $0.9 \%$ and $10.0 \%$, respectively, for both the fresh and the used catalysts in the range of $150-360^{\circ} \mathrm{C}$ (Table S1), suggesting that the amount of coke deposition is $9.2 \%$ for the used $\left(\mathrm{NH}_{4}\right)_{2} \mathrm{RuCl}_{6} / \mathrm{AC}$ catalyst (Table 2 ). Hence, the used $\mathrm{RuCl}_{3} / \mathrm{AC}$ catalyst performs more severe coke deposition compared to the used complex $\left(\mathrm{NH}_{4}\right)_{2} \mathrm{RuCl}_{6} / \mathrm{AC}$ catalyst, in agreement with the specific surface areas change of the used catalysts (Table 1). Coke deposition could reduce the number of surface active sites, thereby reducing the catalytic activity. This demonstrates that the complex $\left(\mathrm{NH}_{4}\right)_{2} \mathrm{RuCl}_{6} / \mathrm{AC}$ catalyst can inhibit the coke deposition and enhance the catalytic activity. 


\subsubsection{The Dispersion of Active Species}

Figure 3 shows the TEM images of Ru-catalysts. For the fresh $\mathrm{RuCl}_{3} / \mathrm{AC}$ catalyst, a few tiny black dots are observed, which are indexed to Ru particles with an average size of $1.22 \mathrm{~nm}$. This indicates that the Ru species is highly dispersed on the carbon support. However, for the fresh $\left(\mathrm{NH}_{4}\right)_{2} \mathrm{RuCl}_{6} / \mathrm{AC}$ catalyst, $\mathrm{Ru}$ particles are not detected, suggesting that Ru species mainly exist in the forms of $\mathrm{Ru}^{4+}$ in the fresh $\left(\mathrm{NH}_{4}\right)_{2} \mathrm{RuCl}_{6} / \mathrm{AC}$ catalyst, which has been proven in the next section. In order to further distinguish the presence or absence of Ru particles on the fresh catalysts, the HRTEM images are shown in the Figure S1. The crystal lattices of $0.21 \mathrm{~nm}$ are observed, which could be attributed to the (101) crystal faces of $\mathrm{Ru}$ metal. It further proves that the Ru particles exist in the fresh $\mathrm{RuCl}_{3} / \mathrm{AC}$ catalyst. As we all know, the dispersion of the active site can affect their catalytic behavior. The $\mathrm{RuCl}_{3} / \mathrm{AC}$ catalyst has a lower conversion of acetylene compared to the $\left(\mathrm{NH}_{4}\right)_{2} \mathrm{RuCl}_{6} / \mathrm{AC}$ catalyst, which could partly be attributed to the fact that the $\mathrm{RuCl}_{3} / \mathrm{AC}$ catalyst has lower dispersion, the larger average $\mathrm{Ru}$ particle size, than the $\left(\mathrm{NH}_{4}\right)_{2} \mathrm{RuCl}_{6} / \mathrm{AC}$ catalyst. This suggests that small Ru particles are more favorable for the acetylene hydrochlorination.

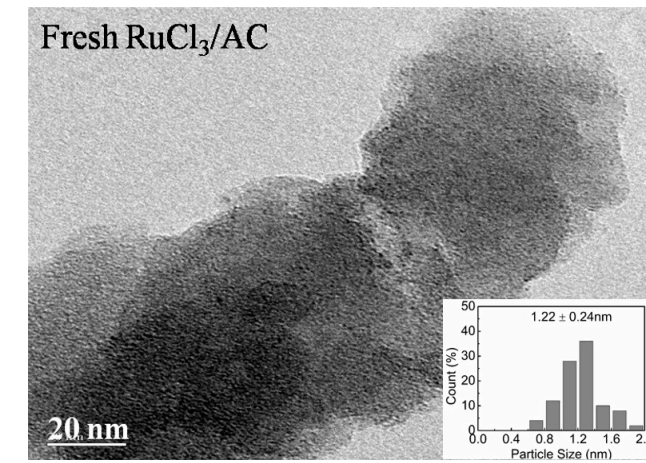

(a)

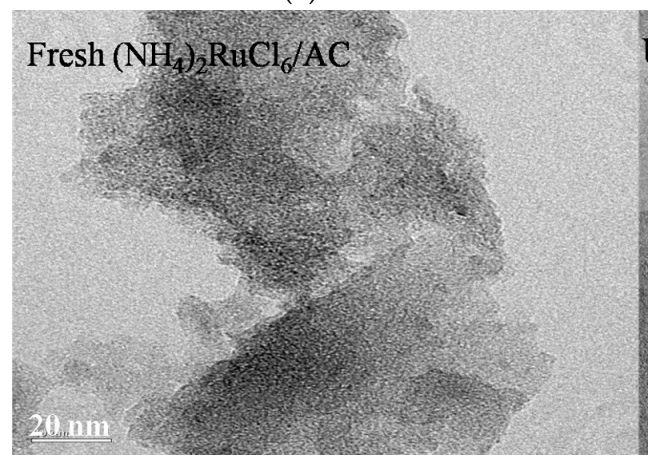

(c)

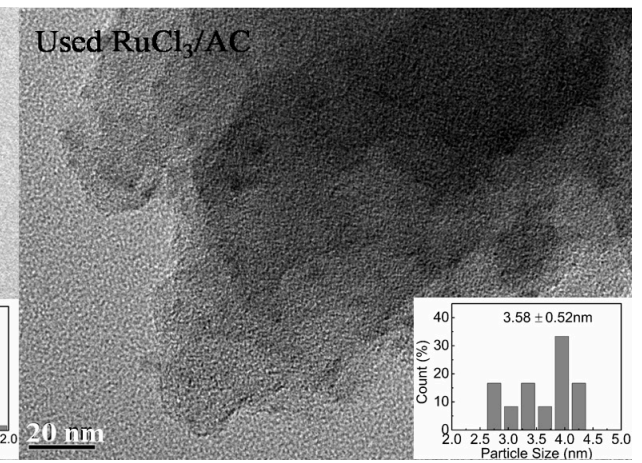

(b)

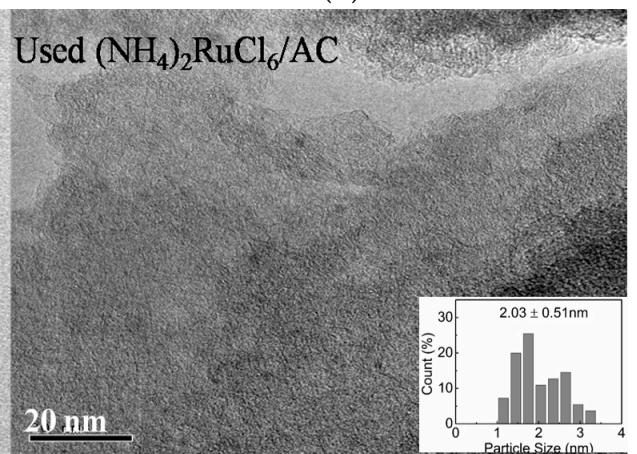

(d)

Figure 3. TEM images of the fresh and used Ru-based catalysts with $1.0 \mathrm{wt} \% \mathrm{Ru}$ loading. (a) Fresh $\mathrm{RuCl}_{3} / \mathrm{AC}$; (b) Used $\mathrm{RuCl}_{3} / \mathrm{AC}$; (c) Fresh $\left(\mathrm{NH}_{4}\right)_{2} \mathrm{RuCl}_{6} / \mathrm{AC}$; (d) Used $\left(\mathrm{NH}_{4}\right)_{2} \mathrm{RuCl}_{6} / \mathrm{AC}$.

For the used catalysts, some slightly larger black dots appear compared to the fresh catalysts, suggesting the aggregation of $\mathrm{Ru}$ particles during the reaction. The used $\left(\mathrm{NH}_{4}\right)_{2} \mathrm{RuCl}_{6} / \mathrm{AC}$ catalyst possesses an average size of about $2.03 \mathrm{~nm}$, and this is smaller than that of the used $\mathrm{RuCl}_{3} / \mathrm{AC}$ catalyst $(3.58 \mathrm{~nm})$. It is demonstrated that less aggregation occurs on the $\left(\mathrm{NH}_{4}\right)_{2} \mathrm{RuCl}_{6} / \mathrm{AC}$ catalyst during the reaction compared to the $\mathrm{RuCl}_{3} / \mathrm{AC}$ catalyst, indicating that the complex $\left(\mathrm{NH}_{4}\right)_{2} \mathrm{RuCl}_{6} / \mathrm{AC}$ catalyst can reduce the aggregation of $\mathrm{Ru}$ particles during the reaction. For the reason why the complex $\left(\mathrm{NH}_{4}\right)_{2} \mathrm{RuCl}_{6} / \mathrm{AC}$ catalysts can reduce the aggregation of $\mathrm{Ru}$ particles during the reaction, we conducted further study. Since the fresh $\mathrm{RuCl}_{3} / \mathrm{AC}$ catalyst has the Ru nanoparticles which could be formed during the catalyst preparation with $\mathrm{RuCl}_{3} \cdot 3 \mathrm{H}_{2} \mathrm{O}$ as the precursor. However, no $\mathrm{Ru}$ nanoparticles exist in the fresh $\left(\mathrm{NH}_{4}\right)_{2} \mathrm{RuCl}_{6} / \mathrm{AC}$ catalyst, suggesting that there is a difference 
in stability between the two metallic precursors and complex $\left(\mathrm{NH}_{4}\right)_{2} \mathrm{RuCl}_{6}$ is more stable than $\mathrm{RuCl}_{3} \cdot 3 \mathrm{H}_{2} \mathrm{O}$. For the used $\mathrm{RuCl}_{3} / \mathrm{AC}$ and $\left(\mathrm{NH}_{4}\right)_{2} \mathrm{RuCl}_{6} / \mathrm{AC}$ catalysts, some $\mathrm{Ru}$ nanoparticles are observed, suggesting the nanoparticles nucleation process is carried on during the reaction. Consequently, the difference of stability of the metallic precursor during the synthesis of the Ru-based catalysts could be one reason that $\left(\mathrm{NH}_{4}\right)_{2} \mathrm{RuCl}_{6} / \mathrm{AC}$ can reduce the aggregation of Ru particles during the reaction.

The XRD pattern of the Ru-based catalysts is displayed in Figure S2. Apart from the amorphous diffraction peaks of the support AC, no distinguishable Ru diffraction peak is detected in the both fresh and used Ru-based catalysts. This result indicates that the size of Ru particles is below $4 \mathrm{~nm}$ and $\mathrm{Ru}$ species is highly dispersed on the carbon support, which is consistent with the results of TEM [26].

\subsubsection{TPR}

Figure 4 shows TPR profiles of the fresh $\mathrm{RuCl}_{3} / \mathrm{AC},\left(\mathrm{NH}_{4}\right)_{2} \mathrm{RuCl}_{6} / \mathrm{AC}$, and activated carbon catalysts. For these catalysts, a broad peak appears in the temperature range of $400-700{ }^{\circ} \mathrm{C}$, which is mainly related to the reduction of functional groups on the activated carbon support. Besides, some $\mathrm{H}_{2}$ consumption peaks are observed in the range $100-400{ }^{\circ} \mathrm{C}$ for the Ru-based catalysts, attributed to the reduction of ruthenium species in these catalysts. The fresh $\mathrm{RuCl}_{3} / \mathrm{AC}$ catalyst exhibits two peaks at 226 and $277{ }^{\circ} \mathrm{C}$, corresponding to the reduction of the $\mathrm{Ru}^{3+}\left(226^{\circ} \mathrm{C}\right)$ and $\mathrm{Ru}^{4+}\left(277^{\circ} \mathrm{C}\right)$, respectively. For the fresh $\left(\mathrm{NH}_{4}\right)_{2} \mathrm{RuCl}_{6} / \mathrm{AC}$ catalyst, only a stronger peak with the temperature at $289^{\circ} \mathrm{C}$ is observed, which is indexed to the $\mathrm{Ru}^{4+}$ species. The result suggests that the Ru species in the complex $\left(\mathrm{NH}_{4}\right)_{2} \mathrm{RuCl}_{6} / \mathrm{AC}$ catalyst exist mainly in the form of high valence ruthenium. Additionally, the higher reduction temperature of the $\mathrm{Ru}^{4+}$ species in the $\left(\mathrm{NH}_{4}\right)_{2} \mathrm{RuCl}_{6} / \mathrm{AC}$ catalyst suggests that the presence of $\mathrm{NH}_{4}{ }^{+}$cation can stabilize the $\mathrm{Ru}^{4+}$ species and inhibit its reduction to metallic $\mathrm{Ru}$. This result might be attributed to the strong interaction between $\mathrm{NH}_{4}{ }^{+}$cation and $\left[\mathrm{RuCl}_{6}\right]^{2-}[37,38]$. For the used $\mathrm{RuCl}_{3} / \mathrm{AC}$ and $\left(\mathrm{NH}_{4}\right)_{2} \mathrm{RuCl}_{6} / \mathrm{AC}$ catalysts, the reduction peak becomes weaker, which could be due to the loss of the Ru species and the reduction of high valence Ru species during the acetylene hydrochlorination reaction. Meanwhile, for the used $\left(\mathrm{NH}_{4}\right)_{2} \mathrm{RuCl}_{6} / \mathrm{AC}$ catalyst, a new reduction peak at $244{ }^{\circ} \mathrm{C}$ is observed, corresponding to the reduction of $\mathrm{Ru}^{3+}$ species. This result is consistent with the next XPS analysis (Table 3).

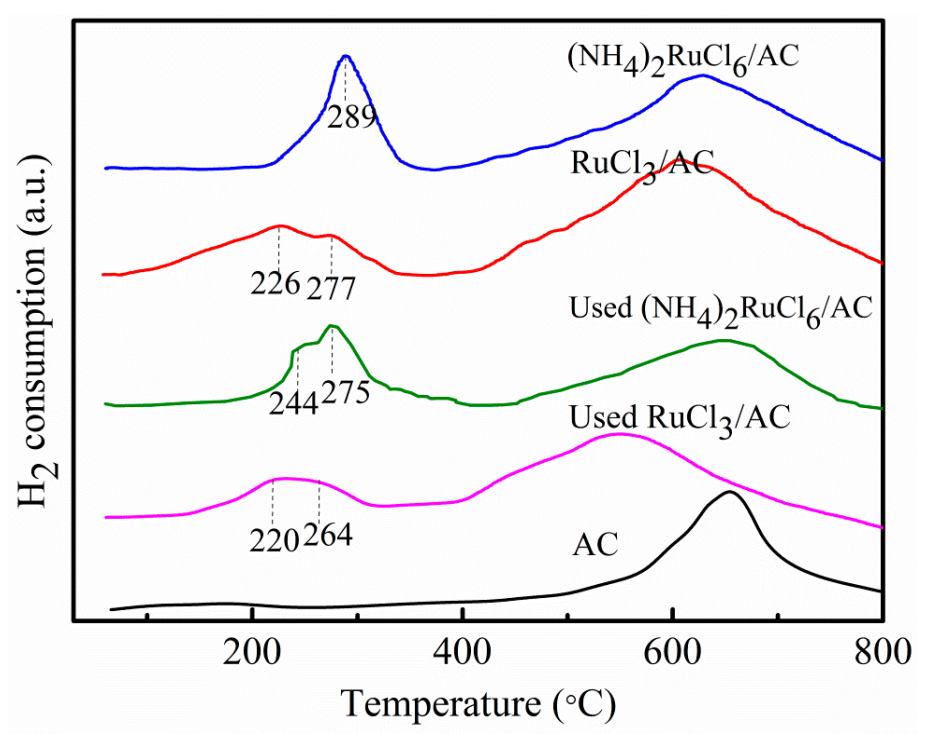

Figure 4. TPR profiles of the Ru-based catalysts with 1.0 wt \% Ru loading. 
Table 3. The relative contents and binding energies of Ru species in the fresh and used catalysts with 1.0 wt \% Ru loading.

\begin{tabular}{|c|c|c|c|c|c|}
\hline \multirow{2}{*}{ Parameters } & \multicolumn{5}{|c|}{ Fresh $\mathrm{RuCl}_{3} / \mathrm{AC}$} \\
\hline & $\mathbf{R} \mathbf{u}^{0}$ & $\mathrm{Ru} / \mathrm{RuO}_{y}$ & $\mathbf{R} \mathbf{u}^{3+}$ & $\mathbf{R} \mathbf{u}^{4+}$ & $\mathbf{R} \mathbf{u}^{x+}$ \\
\hline Area $(\%)$ & 6.1 & 18.2 & 35.9 & 23.7 & 16.1 \\
\hline Binding Energy (eV) & 461.4 & 462.8 & 463.9 & 464.9 & 466.6 \\
\hline \multirow{2}{*}{ Parameters } & \multicolumn{5}{|c|}{ Fresh $\left(\mathrm{NH}_{4}\right)_{2} \mathrm{RuCl}_{6} / \mathrm{AC}$} \\
\hline & $\mathbf{R} \mathbf{u}^{0}$ & $\mathrm{Ru} / \mathrm{RuO}_{y}$ & $\mathbf{R} \mathbf{u}^{3+}$ & $\mathbf{R} \mathbf{u}^{4+}$ & $\mathbf{R} \mathbf{u}^{x+}$ \\
\hline Area $(\%)$ & - & 32.2 & - & 67.8 & - \\
\hline Binding Energy (eV) & - & 462.7 & - & 464.4 & - \\
\hline \multirow{2}{*}{ Parameters } & \multicolumn{5}{|c|}{ Used $\mathrm{RuCl}_{3} / \mathrm{AC}$} \\
\hline & $\mathbf{R} \mathbf{u}^{\mathbf{0}}$ & $\mathrm{Ru} / \mathrm{RuO}_{y}$ & $\mathbf{R} \mathbf{u}^{3+}$ & $\mathbf{R} \mathbf{u}^{4+}$ & $\mathbf{R} \mathbf{u}^{x+}$ \\
\hline Area (\%) & 16.7 & 14.4 & 39.3 & 14.7 & 14.9 \\
\hline Binding Energy (eV) & 461.3 & 462.3 & 463.3 & 464.7 & 466.8 \\
\hline \multirow{2}{*}{ Parameters } & \multicolumn{5}{|c|}{ Used $\left(\mathrm{NH}_{4}\right)_{2} \mathrm{RuCl}_{6} / \mathrm{AC}$} \\
\hline & $\mathbf{R} \mathbf{u}^{\mathbf{0}}$ & $\mathrm{Ru} / \mathrm{RuO}_{y}$ & $\mathbf{R u}^{3+}$ & $\mathbf{R u}^{4+}$ & $\mathbf{R} \mathbf{u}^{x+}$ \\
\hline Area $(\%)$ & 5.5 & 30.0 & 22.5 & 28.1 & 13.9 \\
\hline Binding Energy (eV) & 460.6 & 462.6 & 463.7 & 464.4 & 465.3 \\
\hline
\end{tabular}

\subsubsection{XPS Spectra}

XPS spectra are used to research the valence variations of ruthenium species in the fresh and used $\mathrm{RuCl}_{3} / \mathrm{AC}$ and $\left(\mathrm{NH}_{4}\right)_{2} \mathrm{RuCl}_{6} / \mathrm{AC}$ catalysts. Owing to the binding energy of $\mathrm{Ru} 3 \mathrm{~d}$ orbital overlapping with the binding energy of $C 1 s$, the Ru $3 p$ orbital is chosen for the analysis $[39,40]$. Because the $\mathrm{Ru} 3 \mathrm{p}_{3 / 2}$ peak area and the $\mathrm{Ru} 3 \mathrm{p}_{1 / 2}$ peak area of the $\mathrm{Ru}$ species with the same valence states have a proportional relationship, and the area ratio of $p_{3 / 2}$ and $p_{1 / 2}$ is $2: 1$. Therefore, the only the $R u$ $3 p_{3 / 2}$ peak or the $R u 3 p_{1 / 2}$ peak can represent the valence variations of the whole ruthenium species. Meanwhile, noisy $\mathrm{Ru} 3 \mathrm{p}$ spectrum is not uncommon among carbon-supported catalysts, and the stronger $\mathrm{Ru} 3 \mathrm{p}_{3 / 2}$ signal (relative to $\mathrm{Ru} 3 \mathrm{p}_{1 / 2}$ peak) is employed to analyze the valence variations of the ruthenium species, so as to easy to deal with the XPS spectra and gain clearer deconvolution results. The $\mathrm{Ru} 3 \mathrm{p}_{3 / 2}$ peak is further separated into several different peaks (Figure S3), and the deconvolution results including the binding energy and relative content of different peaks are shown in Table 3. For the fresh $\mathrm{RuCl}_{3} / \mathrm{AC}$ catalyst, there are five types of ruthenium species, including $\mathrm{Ru}^{0}$, $\mathrm{Ru} / \mathrm{RuO}_{y}, \mathrm{Ru}^{3+}, \mathrm{Ru}^{4+}$ and $\mathrm{Ru}^{x+}(x>4)$. For the fresh $\left(\mathrm{NH}_{4}\right)_{2} \mathrm{RuCl}_{6} / \mathrm{AC}$ catalyst, only $\mathrm{Ru} / \mathrm{RuO}_{y}$ and $\mathrm{Ru}^{4+}$ species are observed. The content of $\mathrm{Ru}^{4+}$ species on the fresh $\left(\mathrm{NH}_{4}\right)_{2} \mathrm{RuCl}_{6} / \mathrm{AC}$ catalyst is $67.8 \%$, which is much higher than that of the fresh $\mathrm{RuCl}_{3} / \mathrm{AC}(23.7 \%)$, in good agreement with the $\mathrm{H}_{2}$-TPR result. This can be one reason why the complex $\left(\mathrm{NH}_{4}\right)_{2} \mathrm{RuCl}_{6} / \mathrm{AC}$ catalyst exhibits superior catalytic performance to the monometallic $\mathrm{RuCl}_{3} / \mathrm{AC}$ catalysts. As has been reported, $\mathrm{Ru}^{4+}$ species is considered as the major active ingredient in acetylene hydrochlorination reaction [36].

After $48 \mathrm{~h}$ reaction, for the used $\mathrm{RuCl}_{3} / \mathrm{AC}$ catalyst, the content of $\mathrm{Ru}^{0}$ species increases from $6.1 \%$ to $16.7 \%$, and the change is far higher than that of the $\left(\mathrm{NH}_{4}\right)_{2} \mathrm{RuCl}_{6} / \mathrm{AC}$ catalyst. This may be one reason why the $\mathrm{RuCl}_{3} / \mathrm{AC}$ catalyst rapidly deactivates. In addition, new ruthenium species exist in the used $\left(\mathrm{NH}_{4}\right)_{2} \mathrm{RuCl}_{6} / \mathrm{AC}$ catalyst, which might be attributed to the disproportionate of $\mathrm{Ru}^{4+}$ species during the reaction. It is worthwhile to note that the content of $\mathrm{Ru}^{4+}$ species in the used $\left(\mathrm{NH}_{4}\right)_{2} \mathrm{RuCl}_{6} / \mathrm{AC}$ catalyst is still higher compared with the used $\mathrm{RuCl}_{3} / \mathrm{AC}$ catalyst, in agreement with the catalytic activity (Figure 1). 
2.2.6. The Adsorption Properties of the Reactants and Products on the Ru-Based Catalysts

TPD experiments are used to illustrate the adsorption properties of fresh Ru-based catalysts for $\mathrm{HCl}, \mathrm{C}_{2} \mathrm{H}_{2}$, and $\mathrm{C}_{2} \mathrm{H}_{3} \mathrm{Cl}$. Figure 5 displays the TPD profiles of the fresh $\mathrm{RuCl}_{3} / \mathrm{AC}$ and $\left(\mathrm{NH}_{4}\right)_{2} \mathrm{RuCl}_{6} / \mathrm{AC}$ catalysts, including the $\mathrm{HCl}-\mathrm{TPD}, \mathrm{C}_{2} \mathrm{H}_{2}-\mathrm{TPD}$, and $\mathrm{C}_{2} \mathrm{H}_{3} \mathrm{Cl}$-TPD profiles. It is known that these desorption peak area and temperature can reflect the adsorption property of adsorbed species on the catalysts. In order to eliminate the decomposition peak of complex $\left(\mathrm{NH}_{4}\right)_{2} \mathrm{RuCl}_{6}$, the TPD experiment for the fresh complex $\left(\mathrm{NH}_{4}\right)_{2} \mathrm{RuCl}_{6} / \mathrm{AC}$ catalyst without adsorbing any gas is performed in the pure helium atmosphere. As shown the blue line in Figure $5 \mathrm{a}-\mathrm{c}$, there is an obvious desorption peak at about $300-500{ }^{\circ} \mathrm{C}$ in the He-TPD curve of the $\left(\mathrm{NH}_{4}\right)_{2} \mathrm{RuCl}_{6} / \mathrm{AC}$ catalyst, attributed to the thermal decomposition peak of complex $\left(\mathrm{NH}_{4}\right)_{2} \mathrm{RuCl}_{6}$. This is in agreement with the TG curve of pure complex $\left(\mathrm{NH}_{4}\right)_{2} \mathrm{RuCl}_{6}$ (Figure S4). As showed in Figure 5a, desorption peak at about $300-500{ }^{\circ} \mathrm{C}$ overlaps with the thermal decomposition peak of complex $\left(\mathrm{NH}_{4}\right)_{2} \mathrm{RuCl}_{6}$, hence we chose the desorption peak at about $250{ }^{\circ} \mathrm{C}$ to analyze. The $\mathrm{HCl}$ desorption peak area of the complex $\left(\mathrm{NH}_{4}\right)_{2} \mathrm{RuCl}_{6} / \mathrm{AC}$ catalyst is greater than that of the monometallic $\mathrm{RuCl}_{3} / \mathrm{AC}$ catalyst, suggesting that the adsorption capacity of $\mathrm{HCl}$ on the complex $\left(\mathrm{NH}_{4}\right)_{2} \mathrm{RuCl}_{6} / \mathrm{AC}$ catalyst is much stronger than the adsorption capacity of the monometallic $\mathrm{RuCl}_{3} / \mathrm{AC}$ catalyst. $\mathrm{C}_{2} \mathrm{H}_{2}$-TPD also shows the similar profile. However, the $\mathrm{C}_{2} \mathrm{H}_{2}$ desorption peak area has a small difference between the $\left(\mathrm{NH}_{4}\right)_{2} \mathrm{RuCl}_{6} / \mathrm{AC}$ catalyst and $\mathrm{RuCl}_{3} / \mathrm{AC}$ catalyst (Figure $5 \mathrm{~b}$ ), indicating that the $\left(\mathrm{NH}_{4}\right)_{2} \mathrm{RuCl}_{6} / \mathrm{AC}$ catalyst shows a small effect on the adsorption capacity of $\mathrm{C}_{2} \mathrm{H}_{2}$.
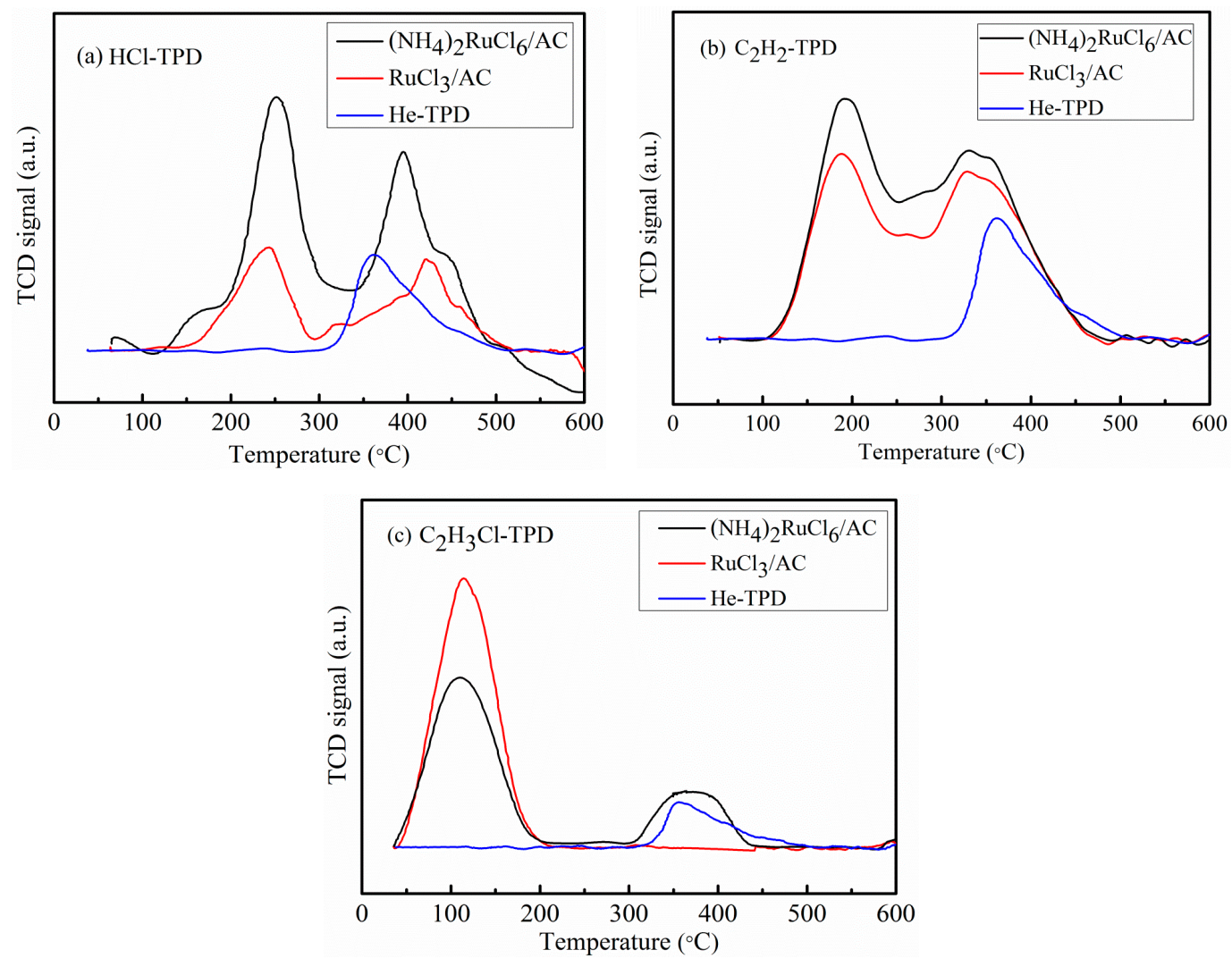

Figure 5. TPD of the fresh $1.0 \mathrm{wt} \%$ Ru-based catalysts (a) HCl-TPD; (b) $\mathrm{C}_{2} \mathrm{H}_{2}$-TPD; (c) $\mathrm{C}_{2} \mathrm{H}_{3} \mathrm{Cl}$-TPD.

For the product $\mathrm{C}_{2} \mathrm{H}_{3} \mathrm{Cl}$, the adsorption capacity on the Ru-based catalysts should be as small as possible. The adsorption capacity of $\mathrm{C}_{2} \mathrm{H}_{3} \mathrm{Cl}$ on the complex $\left(\mathrm{NH}_{4}\right)_{2} \mathrm{RuCl}_{6} / \mathrm{AC}$ catalyst is smaller than that on the monometallic $\mathrm{RuCl}_{3} / \mathrm{AC}$ catalyst (Figure 5c). This result indicates that the presence of $\mathrm{NH}_{4}{ }^{+}$can weaken the VCM adsorption capacity on the complex $\left(\mathrm{NH}_{4}\right)_{2} \mathrm{RuCl}_{6} / \mathrm{AC}$ catalyst, as a result, 
inhibiting the occurrence of coke deposition, in agreement with the result of TG analysis. In conclusion, the presence of $\mathrm{NH}_{4}{ }^{+}$can enhance the adsorption capacity of reactant $\mathrm{HCl}$ and weaken the adsorption capacity of product $\mathrm{C}_{2} \mathrm{H}_{3} \mathrm{Cl}$, which is beneficial for the acetylene hydrochlorination reaction. Thus, the complex $\left(\mathrm{NH}_{4}\right)_{2} \mathrm{RuCl}_{6} / \mathrm{AC}$ catalyst possesses a better catalytic activity for the reaction.

\subsubsection{Stability Assessment of Ru-Based Catalysts}

To further testify the superior performance of $\left(\mathrm{NH}_{4}\right)_{2} \mathrm{RuCl}_{6} / \mathrm{AC}$ catalyst, the long-term stability of the $\mathrm{RuCl}_{3} / \mathrm{AC}$ and $\left(\mathrm{NH}_{4}\right)_{2} \mathrm{RuCl}_{6} / \mathrm{AC}$ catalysts was assessed under the conditions of $170{ }^{\circ} \mathrm{C}$ and $\operatorname{GHSV}\left(\mathrm{C}_{2} \mathrm{H}_{2}\right)$ of $360 \mathrm{~h}^{-1}$ (half mass of catalyst). As shown in the Figure $\mathrm{S} 5$, the $\mathrm{RuCl}_{3} / \mathrm{AC}$ catalyst shows an initial acetylene conversion of $57.8 \%$, and decreases to $30.5 \%$ after $100 \mathrm{~h}$ reaction. While, for the complex $\left(\mathrm{NH}_{4}\right)_{2} \mathrm{RuCl}_{6} / \mathrm{AC}$ catalyst, the acetylene conversion is $78.6 \%$, and then decreases to $68.6 \%$ after $100 \mathrm{~h}$ reaction. Therefore, the comparison of stability of $\mathrm{RuCl}_{3} / \mathrm{AC}$ and $\left(\mathrm{NH}_{4}\right)_{2} \mathrm{RuCl}_{6} / \mathrm{AC}$ catalysts demonstrates that the $\left(\mathrm{NH}_{4}\right)_{2} \mathrm{RuCl}_{6} / \mathrm{AC}$ catalyst is more stable than the $\mathrm{RuCl}_{3} / \mathrm{AC}$ catalyst.

In order to show the amount of coke deposited on the used catalysts, we also carried out the TG analysis. Figure $\mathrm{S} 6$ shows the TG analysis profiles of the both fresh and used $\mathrm{RuCl}_{3} / \mathrm{AC}$ and $\left(\mathrm{NH}_{4}\right)_{2} \mathrm{RuCl}_{6} / \mathrm{AC}$ catalysts. The amount of coke deposited on the used catalysts is listed in the Table S2. As seen in the Table S2, the amount of coke deposition on the complex $\left(\mathrm{NH}_{4}\right)_{2} \mathrm{RuCl}_{6} / \mathrm{AC}$ catalyst is $13.5 \%$, which is lower than that of the used $\mathrm{RuCl}_{3} / \mathrm{AC}$ catalyst (19.7\%). This suggests that the capacity against coking of the $\left(\mathrm{NH}_{4}\right)_{2} \mathrm{RuCl}_{6} / \mathrm{AC}$ catalyst is better than that of the $\mathrm{RuCl}_{3} / \mathrm{AC}$ catalyst.

\section{Experimental Section}

\subsection{Materials}

Coconut activated carbon (AC, 20-40 mesh) was purchased from Fujian S.S Activated Carbon Industry Science and Technology Co., Ltd. (Fujian, China). $\mathrm{RuCl}_{3} \cdot 3 \mathrm{H}_{2} \mathrm{O}$ (Ru content $\geq 38 \%$, purity $\geq 99 \%$ ) and ammonium chloride $\left(\mathrm{NH}_{4} \mathrm{Cl}\right.$, purity $\left.\geq 99.5 \%\right)$ were purchased from Tianjin Fengchuan Chemical Reagent Technology Co., Ltd. (Tianjin, China). Ammonium hexachlororuthenate (IV) $\left(\left(\mathrm{NH}_{4}\right)_{2} \mathrm{RuCl}_{6}\right.$, Ru content $\geq 28.4 \%$, purity $\left.\geq 99 \%\right)$ was purchased from Beijing InnoChem Science and Technology Co., Ltd. (Beijing, China). In this work, all chemicals were commercially available, and directly used without further purification.

\subsection{Catalyst Preparation}

The Ru-based catalysts were prepared via an incipient wetness impregnation method. In the process, distilled water was used as a solvent and coconut activated carbon (AC, 20-40 mesh) was used as the support. $\left(\mathrm{NH}_{4}\right)_{2} \mathrm{RuCl}_{6}$ and $\mathrm{RuCl}_{3} \cdot 3 \mathrm{H}_{2} \mathrm{O}$ were used as the catalysts precursors to obtain the $\left(\mathrm{NH}_{4}\right)_{2} \mathrm{RuCl}_{6} / \mathrm{AC}$ and $\mathrm{RuCl}_{3} / \mathrm{AC}$ catalysts, respectively. To prepare $\left(\mathrm{NH}_{4}\right)_{2} \mathrm{RuCl}_{6} / \mathrm{AC}$ catalyst with $1.0 \mathrm{wt} \% \mathrm{Ru}$ loading, an $\left(\mathrm{NH}_{4}\right)_{2} \mathrm{RuCl}_{6}$ aqueous solution was dropped quantitatively into the activated carbon support at room temperature under stirring, followed by the impregnation at $60^{\circ} \mathrm{C}$ for $12 \mathrm{~h}$. Finally, the catalysts were dried at $150{ }^{\circ} \mathrm{C}$ for $12 \mathrm{~h}$. The $\mathrm{RuCl}_{3} / \mathrm{AC}$ catalyst with $1.0 \mathrm{wt} \% \mathrm{Ru}$ loading was prepared using the same procedure. In addition, the precise $\mathrm{Ru}$ loading amount was measured by ICP analysis. For the fresh $\mathrm{RuCl}_{3} / \mathrm{AC}$ and $\left(\mathrm{NH}_{4}\right)_{2} \mathrm{RuCl}_{6} / \mathrm{AC}$ catalysts, the precise loading amounts are 0.86 and $0.87 \mathrm{wt} \%$, respectively.

\subsection{Catalyst Characterization}

The specific surface areas of these catalysts were determined by the $\mathrm{N}_{2}$ adsorption/desorption experiments which were carried out by volumetric adsorption system (Quatachrome Instruments, Boynton Beach, FL, USA). Firstly, these catalysts were heated at $200{ }^{\circ} \mathrm{C}$ for $4 \mathrm{~h}$ to degas, and then analyzed using liquid nitrogen adsorption at $77 \mathrm{~K}$. 
Transmission electron microscopy (TEM) was performed using a JEM2100F TEM (JEOL Ltd., Tokyo, Japan) at an accelerating voltage of $200 \mathrm{kV}$. Before each test of TEM, the samples with a fine powder were dispersed in ethanol and then laid on a TEM grid.

The amount of coke deposition of the used catalysts were measured using thermo gravimetric analysis (TGA) with TG-DTG simultaneous thermal analyzer (NETZSCH STA 449F3 Jupiter ${ }^{\circledR}$, Selb, Germany) in an air atmosphere at a flow rate of $50 \mathrm{~mL} \cdot \mathrm{min}^{-1}$. The temperature was increased from 35 to $900{ }^{\circ} \mathrm{C}$ at a rate of $10^{\circ} \mathrm{C} \cdot \mathrm{min}^{-1}$.

$\mathrm{X}$-ray diffraction (XRD) spectra were acquired using a RigakuD/MAX-2500 X-ray diffractometer (Japan Rigaku Co., Ltd., Tokyo, Japan) with monochromatized Cu K $\alpha$ radiation $(\lambda=1.5406 \AA$ ) at a scanning rate of $5^{\circ} \cdot \mathrm{min}^{-1}$, with $2 \theta$ ranging from $10^{\circ}$ to $90^{\circ}$.

Temperature programmed reduction (TPR) was used to determine the reduction behavior of the fresh catalysts. During TPR test, the temperature of the system (Quantachrome Instruments) was increased from 35 to $900{ }^{\circ} \mathrm{C}$ at a rate of $10{ }^{\circ} \mathrm{C} \cdot \mathrm{min}^{-1}$ with a $10 \% \mathrm{H}_{2} /$ Ar flowing.

$\mathrm{X}$-ray photoelectron spectra (XPS) (ULVAC-PHI, Inc., Chigasaki, Japan) was used to measure the binding energy of the fresh and used catalysts. The $\mathrm{C} 1 \mathrm{~s}$ line $(284.6 \mathrm{eV})$ was used as the calibration of the spectra.

Temperature programmed desorption (TPD) was performed using an AutoChem BET TPR/TPD analyzer (Quantachrome Instruments). TPD was used to measure the adsorption capacity of the catalysts for reactants and product. For $\mathrm{C}_{2} \mathrm{H}_{2}$-TPD and HCl-TPD, before the desorption experiments, the samples were first pre-treated at $170{ }^{\circ} \mathrm{C}$ for $4 \mathrm{~h}$ under $\mathrm{C}_{2} \mathrm{H}_{2}$ and $\mathrm{HCl}$, respectively. Then, the samples were treated with pure $\mathrm{He}$ for $0.5 \mathrm{~h}$ followed by the desorption experiments which were performed from 50 to $800^{\circ} \mathrm{C}$ at a rate of $10^{\circ} \mathrm{C} \cdot \mathrm{min}^{-1}$. For the $\mathrm{C}_{2} \mathrm{H}_{3} \mathrm{Cl}$-TPD experiment, the method was similar to the above process, except the pre-treatment condition of $\mathrm{C}_{2} \mathrm{H}_{3} \mathrm{Cl}$ was $1 \mathrm{~h}$ on the TPR/TPD equipment at $170{ }^{\circ} \mathrm{C}$. The weight of each sample was fixed at $110 \mathrm{mg}$ for the above all experiments.

\subsection{Catalyst Performance Evaluation}

The catalytic performance was performed in a fixed-bed reactor (inner diameter $10 \mathrm{~mm}$ ) for acetylene hydrochlorination reaction. The reactor temperature was regulated using a CKW-1100 temperature controller from the Chaoyang Automation Instrument Factory (Beijing, China).

Before reaction, the reaction system was purged with nitrogen for $30 \mathrm{~min}$ to remove air and water from the reactor. Then, the reactant $\mathrm{HCl}\left(15 \mathrm{~mL} \cdot \mathrm{min}^{-1}\right)$ was fed into the reactor containing catalyst of $5 \mathrm{~mL}$ via calibrated mass flow controllers to activate the catalyst, after $30 \mathrm{~min}$, followed by the reactant $\mathrm{C}_{2} \mathrm{H}_{2}\left(16.5 \mathrm{~mL} \cdot \mathrm{min}^{-1}\right)$ with an hourly space velocity (GHSV) of $180 \mathrm{~h}^{-1}$ at $170{ }^{\circ} \mathrm{C}$. In view of the safety and the catalyst test under a mild condition, the pressure of the reactants, $\mathrm{HCl}$ and $\mathrm{C}_{2} \mathrm{H}_{2}$, was chosen in the range of 1.1-1.2 bar [41]. The exhaust gas from the reactor was firstly passed through $\mathrm{NaOH}$ solution which was used to absorb the unreacted $\mathrm{HCl}$ and then introduced into a Beifen 3420A gas chromatograph (Beifen-Ruili Analytical Instrument (Group) Co., Ltd., Beijing, China) to analyze product components.

\section{Conclusions}

In this work, a commercially available $\mathrm{Ru}(\mathrm{IV})$ complex $\left(\mathrm{NH}_{4}\right)_{2} \mathrm{RuCl}_{6}$ as a catalyst precursor was applied to the acetylene hydrochlorination reaction. The $\left(\mathrm{NH}_{4}\right)_{2} \mathrm{RuCl}_{6} / \mathrm{AC}$ catalyst exhibits excellent catalytic performance for the acetylene hydrochlorination reaction. After $48 \mathrm{~h}$ reaction, it shows an acetylene conversion of $87.3 \%$ under the $\mathrm{C}_{2} \mathrm{H}_{2}(G H S V)$ of $180 \mathrm{~h}^{-1}$, the reaction temperature of $170{ }^{\circ} \mathrm{C}$. Through characterizations of low-temperature $\mathrm{N}_{2}$ adsorption/desorption, TG, TEM, XRD, TPR, XPS, and TPD techniques, it is confirmed that the complex $\left(\mathrm{NH}_{4}\right)_{2} \mathrm{RuCl}_{6} / \mathrm{AC}$ catalyst contains abundant $\mathrm{Ru}(\mathrm{IV})$ species which is the major active ingredient for acetylene hydrochlorination; $\mathrm{NH}_{4}{ }^{+}$species can interact strongly with Ru species, which can weaken the occurrence of coking deposition and inhibit agglomeration of $\mathrm{Ru}$ metal particles; In addition, the presence of $\mathrm{NH}_{4}{ }^{+}$can change the adsorption property of Ru-based catalyst, strengthening the adsorption capacity of reactant $\mathrm{HCl}$ and weakening 
the adsorption capacity of product VCM, which are beneficial for the acetylene hydrochlorination reaction. As the results demonstrate, the commercially available complex $\left(\mathrm{NH}_{4}\right)_{2} \mathrm{RuCl}_{6}$ as a catalyst precursor shows excellent catalytic performance for acetylene hydrochlorination.

Supplementary Materials: The following are available online at www.mdpi.com/2073-4344/7/1/17/s1, Table S1: Weight loss of fresh and used catalysts with $1.0 \mathrm{wt} \% \mathrm{Ru}$ loading under different temperature ranges, Table S2: The amount of coke deposition on the used $1.0 \mathrm{wt} \%$ Ru-based catalysts, Figure S1: TEM images of the fresh Ru-based catalysts with 1.0 wt \% Ru loading. (a) Fresh $\mathrm{RuCl}_{3} / \mathrm{AC}$; (b) Fresh $\left(\mathrm{NH}_{4}\right)_{2} \mathrm{RuCl}_{6} / \mathrm{AC}$; (c) HRTEM image of Fresh $\mathrm{RuCl}_{3} / \mathrm{AC}$; (d) HRTEM image of Fresh $\left(\mathrm{NH}_{4}\right)_{2} \mathrm{RuCl}_{6} / \mathrm{AC}$, Figure S2: XRD patterns of the fresh and used Ru-based catalysts with 1.0 wt \% Ru loading, Figure S3: XPS patterns of Ru 3p $\mathrm{p}_{3 / 2}$ for fresh and used 1.0 wt \% Ru-catalysts. (a) Fresh $\mathrm{RuCl}_{3} / \mathrm{AC}$; (b) Used $\mathrm{RuCl}_{3} / \mathrm{AC}$; (c) Fresh $\left(\mathrm{NH}_{4}\right)_{2} \mathrm{RuCl}_{6} / \mathrm{AC}$; (d) Used $\left(\mathrm{NH}_{4}\right)_{2} \mathrm{RuCl}_{6} / \mathrm{AC}$, Figure S4: TG curve of complex $\left(\mathrm{NH}_{4}\right)_{2} \mathrm{RuCl}_{6}$ under nitrogen atmosphere, Figure S5: Comparison of stability of $\mathrm{RuCl}_{3} / \mathrm{AC}$ and $\left(\mathrm{NH}_{4}\right)_{2} \mathrm{RuCl}_{6} / \mathrm{AC}$. Reaction conditions: $\mathrm{T}=170^{\circ} \mathrm{C}$, $\operatorname{GHSV}\left(\mathrm{C}_{2} \mathrm{H}_{2}\right)=360 \mathrm{~h}^{-1}, V(\mathrm{HCl}) / V\left(\mathrm{C}_{2} \mathrm{H}_{2}\right)=1.1$, the Ru loading content $=1 \mathrm{wt} \%$, Figure S6: TG and DTG curves of the fresh and used $1.0 \mathrm{wt} \%$ Ru-based catalysts $(\mathbf{a}) \mathrm{RuCl}_{3} / \mathrm{AC},(\mathbf{b})\left(\mathrm{NH}_{4}\right)_{2} \mathrm{RuCl}_{6} / \mathrm{AC}$.

Acknowledgments: We gratefully acknowledge the support by the Special Funds for Major State Research Development Program of China (the 973 Program, No. 2012CB720302) and National Natural Science Foundation of China (NSFC) (21576205).

Author Contributions: Junjie Gu wrote the manuscript; Yumiao Gao carried out and analyzed all the experimental work; Jinli Zhang and Wei Li supervised all the study; Yanzhao Dong participated in the interpretation of the results; You Han is the corresponding author and responsible for the manuscript.

Conflicts of Interest: The authors declare no conflict of interest.

\section{References}

1. Wei, X.; Shi, H.; Qian, W.; Luo, G.; Jin, Y.; Wei, F. Gas-phase catalytic hydrochlorination of acetylene in a two-stage fluidized-bed reactor. Ind. Eng. Chem. Res. 2009, 48, 128-133. [CrossRef]

2. Zhu, M.; Wang, Q.; Chen, K.; Wang, Y.; Huang, C.; Dai, H.; Yu, F.; Kang, L.; Dai, B. Development of a heterogeneous non-mercury catalyst for acetylene hydrochlorination. ACS Catal. 2015, 5, 5306-5316. [CrossRef]

3. Mackey, T.K.; Contreras, J.T.; Liang, B.A. The Minamata Convention on Mercury: Attempting to address the global controversy of dental amalgam use and mercury waste disposal. Sci. Total Environ. 2014, 472, 125-129. [CrossRef] [PubMed]

4. Smith, D.M.; Walsh, P.M.; Slager, T.L. Studies of silica-supported metal chloride catalysts for the vapor-phase hydrochlorination of acetylene. J. Catal. 1968, 11, 113-130. [CrossRef]

5. Shinoda, K. The vapor-phase hydrochlorination of acetylene over metal chlorides supported on activated carbon. Catal. Lett. 1975, 219-220.

6. Hutchings, G.J. Vapor phase hydrochlorination of acetylene: Correlation of catalytic activity of supported metal chloride catalysts. J. Catal. 1985, 96, 292-295. [CrossRef]

7. Conte, M.; Carley, A.; Attard, G.; Herzing, A.; Kiely, C.J.; Hutchings, G.J. Hydrochlorination of acetylene using supported bimetallic Au-based catalysts. J. Catal. 2008, 257, 190-198. [CrossRef]

8. Conte, M.; Carley, A.F.; Hutchings, G.J. Reactivation of a carbon-supported gold catalyst for the hydrochlorination of acetylene. Catal. Lett. 2008, 124, 165-167. [CrossRef]

9. Nkosi, B.; Adams, M.D.; Coville, N.J.; Hutchings, G.J. Hydrochlorination of acetylene using carbon-supported gold catalysts: A study of catalyst reactivation. J. Catal. 1991, 128, 378-386. [CrossRef]

10. Wang, S.; Shen, B.; Song, Q. Kinetics of acetylene hydrochlorination over bimetallic Au-Cu/C catalyst. Catal. Lett. 2010, 134, 102-109. [CrossRef]

11. Zhang, J.; He, Z.; Li, W.; Han, Y. Deactivation mechanism of $\mathrm{AuCl}_{3}$ catalyst in acetylene hydrochlorination reaction: A DFT study. RSC Adv. 2012, 2, 4814-4821. [CrossRef]

12. Zhang, H.; Dai, B.; Wang, X.; Xu, L.; Zhu, M. Hydrochlorination of acetylene to vinyl chloride monomer over bimetallic Au-La/SAC catalysts. J. Ind. Eng. Chem. 2012, 18, 49-54. [CrossRef]

13. Zhang, H.; Dai, B.; Wang, X.; Li, W.; Han, Y.; Gu, J.; Zhang, J. Non-mercury catalytic acetylene hydrochlorination over bimetallic $\mathrm{Au}-\mathrm{Co}(\mathrm{III}) / \mathrm{SAC}$ catalysts for vinyl chloride monomer production. Green Chem. 2013, 15, 829-836. [CrossRef] 
14. Pu, Y.; Zhang, J.; Wang, X.; Zhang, H.; Yu, L.; Dong, Y.; Li, W. Bimetallic Au-Ni/CSs catalysts for acetylene hydrochlorination. Catal. Sci. Technol. 2014, 4, 4426-4432. [CrossRef]

15. Zhang, H.; Dai, B.; Li, W.; Wang, X.; Zhang, J.; Zhu, M.; Gu, J. Non-mercury catalytic acetylene hydrochlorination over spherical activated-carbon-supported Au-Co(III)-Cu(II) catalysts. J. Catal. 2014, 316, 141-148. [CrossRef]

16. Zhao, J.; Xu, J.; Xu, J.; Ni, J.; Zhang, T.; Xu, X.; Li, X. Activated-carbon-supported gold-cesium(I) as highly effective catalysts for hydrochlorination of acetylene to vinyl chloride. ChemPlusChem 2015, 80, $196-201$. [CrossRef]

17. Zhang, H.; Li, W.; Li, X.; Zhao, W.; Gu, J.; Qi, X.; Dong, Y.; Dai, B.; Zhang, J. Non-mercury catalytic acetylene hydrochlorination over bimetallic Au-Ba(II)/AC catalysts. Catal. Sci. Technol. 2015, 5, 1870-1877. [CrossRef]

18. Zhao, J.; Zeng, J.; Cheng, X.; Wang, L.; Yang, H.; Shen, B. An Au-Cu bimetal catalyst for acetylene hydrochlorination with renewable $\gamma-\mathrm{Al}_{2} \mathrm{O}_{3}$ as the support. RSC Adv. 2015, 5, 16727-16734. [CrossRef]

19. Hong, G.; Tian, X.; Jiang, B.; Liao, Z.; Wang, J.; Yang, Y.; Zheng, J. Improvement of performance of a $\mathrm{Au}-\mathrm{Cu} / \mathrm{AC}$ catalyst using thiol for acetylene hydrochlorination reaction. RSC Adv. 2016, 6, 3806-3814. [CrossRef]

20. Du, Y.; Hu, R.; Jia, Y.; Zhou, Q.; Meng, W.; Yang, J. CuCl 2 promoted low-gold-content Au/C catalyst for acetylene hydrochlorination prepared by ultrasonic-assisted impregnation. J. Ind. Eng. Chem. 2016, 37, 32-41. [CrossRef]

21. Yin, X.; Huang, C.; Kang, L.; Zhu, M.; Dai, B. Novel $\mathrm{AuCl}_{3}$-thiourea catalyst with a low Au content and an excellent catalytic performance for acetylene hydrochlorination. Catal. Sci. Technol. 2016, 6, 4254-4259. [CrossRef]

22. Zhu, M.; Kang, L.; Su, Y.; Zhang, J.; Zhang, S.; Dai, B. $\mathrm{MCl}_{x}(\mathrm{M}=\mathrm{Hg}, \mathrm{Au}, \mathrm{Ru} ; x=2,3)$ catalyzed hydrochlorination of acetylene-A density functional theory study. Can. J. Chem. 2013, 91, 120-125. [CrossRef]

23. Sheng, W.; Guo, C.; Li, W. Acetylene hydrochlorination over bimetallic Ru-based catalysts. RSC Adv. 2013, 3, 21062-21068.

24. Jin, Y.; Li, G.; Zhang, J.; Pu, Y.; Li, W. Effects of potassium additive on the activity of Ru catalyst for acetylene hydrochlorination. RSC Adv. 2015, 5, 37774-37779. [CrossRef]

25. Xu, J.; Zhao, J.; Zhang, T.; Di, X.; Gu, S.; Ni, J.; Li, X. Ultra-low Ru-promoted $\mathrm{CuCl}_{2}$ as highly active catalyst for the hydrochlorination of acetylene. RSC Adv. 2015, 5, 38159-38163. [CrossRef]

26. Zhang, H.; Li, W.; Jin, Y.; Sheng, W.; Hu, M.; Wang, X.; Zhang, J. Ru-Co(III)-Cu(II)/SAC catalyst for acetylene hydrochlorination. Appl. Catal. B 2016, 189, 56-64. [CrossRef]

27. Li, G.; Li, W.; Zhang, H.; Pu, Y.; Sun, M.; Zhang, J. Non-mercury catalytic acetylene hydrochlorination over Ru catalysts enhanced by carbon nanotubes. RSC Adv. 2015, 5, 9002-9008. [CrossRef]

28. Hou, L.; Zhang, J.; Pu, Y.; Li, W. Effects of nitrogen-dopants on Ru-supported catalysts for acetylene hydrochlorination. RSC Adv. 2016, 6, 18026-18032. [CrossRef]

29. Xu, N.; Zhu, M.; Zhang, J.; Zhang, H.; Dai, B. Nitrogen functional groups on an activated carbon surface to effect the ruthenium catalysts in acetylene hydrochlorination. RSC Adv. 2015, 5, 86172-86178. [CrossRef]

30. Xu, H.; Zhou, K.; Si, J.; Li, C.; Luo, G. A ligand coordination approach for high reaction stability of anAu-Cu bimetallic carbon-based catalyst in the acetylene hydrochlorination process. Catal. Sci. Technol. 2016, 6, 1357-1366. [CrossRef]

31. Johnston, P.; Carthey, N.; Hutchings, G.J. Discovery, development, and commercialization of gold catalysts for acetylene hydrochlorination. J. Am. Chem. Soc. 2015, 137, 14548-14557. [CrossRef] [PubMed]

32. Huang, C.; Zhu, M.; Kang, L.; Dai, B. A novel high-stability Au(III)/Schiff-based catalyst for acetylene hydrochlorination reaction. Catal. Commun. 2014, 54, 61-65. [CrossRef]

33. Dong, Y.; Li, W.; Yan, Z.; Zhang, J. Hydrochlorination of acetylene catalyzed by an activated carbon supported chlorotriphenylphosphine gold complex. Catal. Sci. Technol. 2016, 6, 7946-7955. [CrossRef]

34. Albani, D.; Li, Q.; Vilé, G.; Mitchell, S.; Almora-Barrios, N.; Witte, P.; Lopez, N.; Perez-Ramirez, J. Interfacial acidity inligand-modified ruthenium nanoparticles boosts the hydrogenation of levulinic acid to gamma-valerolactone. Green Chem. 2017. [CrossRef]

35. Dérien, S.; Klein, H.; Bruneau, C. Selective ruthenium-catalyzed hydrochlorination of alkynes: One-step synthesis of vinylchlorides. Angew. Chem. Int. Ed. 2015, 54, 1-5. [CrossRef] [PubMed] 
36. Pu, Y.; Zhang, J.; Yu, L.; Jin, Y.; Li, W. Active ruthenium species in acetylene hydrochlorination. Appl. Catal. A 2014, 488, 28-36. [CrossRef]

37. Prager, M.; Press, W.; Alefeld, B.; Huller, A. Rotational states of the $\mathrm{NH}_{4}{ }^{+}$ion in $\left(\mathrm{NH}_{4}\right)_{2} \mathrm{SnCl}_{6}$ by inelastic neutron scattering. J. Chem. Phys. 1977, 67, 5126-5132. [CrossRef]

38. Otnest, K.; Svare, I. Inelastic neutron scattering and potential shape in ammonium hexachlorides. J. Phys. C 1979, 12, 3899-3905. [CrossRef]

39. Costa, V.V.; Jacinto, M.J.; Rossi, L.M.; Landers, R.; Gusevskaya, E.V. Aerobic oxidation of monoterpenic alcohols catalyzed by ruthenium hydroxide supported on silica-coated magnetic nanoparticles. J. Catal. 2011, 282, 209-214. [CrossRef]

40. Bo, Z.; Hu, D.; Kong, J.; Yan, J.; Cen, K. Performance of vertically oriented graphene supported platinum-ruthenium bimetallic catalyst for methanol oxidation. J. Power Sources 2015, 273, 530-537. [CrossRef]

41. Conte, M.; Carley, A.; Heirene, C.; Willock, D.; Johnston, P.; Hutchings, G.J. Hydrochlorination of acetylene using a supported gold catalyst: A study of the reaction mechanism. J. Catal. 2007, 250, 231-239. [CrossRef]

(C) 2017 by the authors; licensee MDPI, Basel, Switzerland. This article is an open access article distributed under the terms and conditions of the Creative Commons Attribution (CC-BY) license (http://creativecommons.org/licenses/by/4.0/). 